The TTIP's impact: bringing in the missing issue

一

Martin Myant and Ronan O'Brien

Working Paper 2015.01

etul. 


\section{The TTIP's impact: bringing in the missing issue}

Martin Myant and Ronan O'Brien

Working Paper 2015.01

european trade union institute 
Martin Myant is a senior researcher at the European Trade Union Institute (ETUI) in Brussels. Ronan O'Brien is an independent researcher, based in Brussels. Contact: mmyant@etui.org

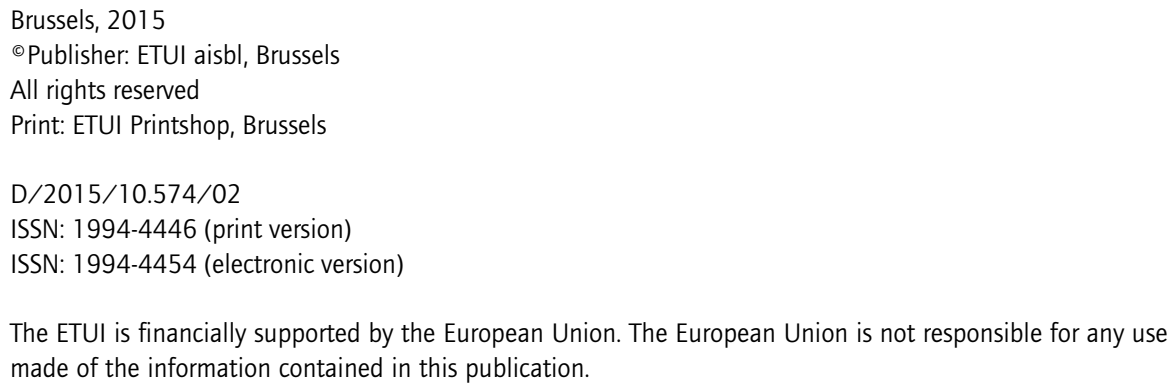




\section{Contents}

Summary $\ldots \cdots \cdots \cdots \cdots \cdots \cdots \cdots \cdots \cdots \cdots \cdots \cdots \cdots \cdots \cdots \cdots \cdots \cdots \cdots \cdots \cdots \cdots \cdots \cdots \cdots \cdots \cdots \cdots \cdots \cdots \cdots \cdots \cdots \cdots \cdots \cdots \cdots \cdots \cdots \cdots \cdots \cdots \cdots \cdots \cdots \cdots \cdots$

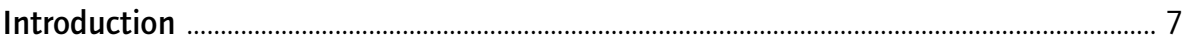

Part I The view of the TTIP economic impact studies ………………........................... 10

1. Introduction to the studies .......................................................................................... 10

2. CEPR and Ecorys impact studies and their findings ................................................ 11

3. The Ifo impact studies ....................................................................................... 15

Part II A closer look at regulations in relation to the TTIP ......................................... 21

1. Transatlantic differences in regulations and how the TTIP proposes to deal with these ................................................................................................. 21

2. Taking regulatory benefits into account in the TTIP .............................................. 25

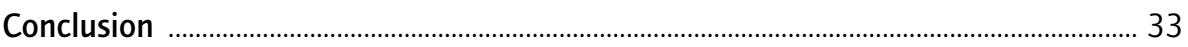

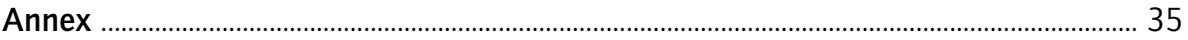

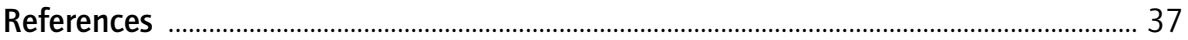





\section{Summary}

The Transatlantic Trade and Investment Partnership (TTIP) has been under negotiation between the European Union and the USA since July 2013 with the relevant parties predicting very substantial economic benefits. These are to come mostly from the removal of differences in regulations, considered as non-tariff barriers to trade and investment. It would be done by making 'compatible' the different regulations that currently require businesses to comply with two sets of rules. A closer look at the results of the economic studies used to support these claims shows that they do not justify the official optimism.

The predicted gains on the most optimistic assumptions, for example for growth - one-twentieth of one per cent increase in growth per annum for 10 years - and for incomes - the equivalent of a cup of coffee per person per week - are in fact extremely small.

The studies that consider employment changes give a very small increase with one partial exception, which predicts two million new jobs in the EU and US over 10-20 years, still just $0.6 \%$ of the 360 million employed. However, this does not appear to take account of many jobs lost, and a much lower figure is given by another analysis from the same group which does. Another study examines job displacement and predicts it to be very low, but the study appears to underestimate considerably the problems involved, especially in a European context.

A closer examination of regulations on the two sides of the Atlantic shows considerable differences in several key areas, as well in the regulatory systems and the technical standards approaches that support them. The task of the TTIP will be very difficult in quite a number of domains.

The way in which the TTIP proposes to deal with regulations may well lead to different regulatory systems being put in competition without any agreed floor. A race to the bottom is then a very possible result when there are differences in costs associated with the lower level of regulation, which appears to be the case in quite a number of areas.

Crucially, the way regulations are considered in the TTIP, and in the analysis of the studies estimating their economic impact, is entirely one-sided. Regulations are considered only as costs for business and the often far greater benefits they bring to society at large as well as in many cases businesses too, are ignored. Empirical economic studies find that the benefits of regulations 
taken in aggregate far outweigh the costs incurred, and the same is true for a number of specific areas illustrated here. If the TTIP processes were to diminish these large benefits to any significant degree, the result is likely to considerably outweigh the tiny economic gains forecast.

From the information available so far, the workings of the TTIP institutions and the overriding legal force to be granted to them may well lead to the control of regulations being largely removed from effective democratic control. With an apparent likely core position for large businesses and their associations in these TTIP regulatory processes, and an incentive to push for regulating in their private interest, regulating in the broader public interest appears under threat. This in itself could be the most problematic outcome of the TTIP.

A more balanced examination of the impact of the TTIP needs to take these issues and their potential effects into account. 


\section{Introduction}

Formal negotiation of the Transatlantic Trade and Investment Partnership (TTIP) between representatives of the European Union and the USA started in July 2013, though with considerable secrecy over the negotiations, making it difficult for the public to identify what the results might be in many important areas. If successful it promised a considerable impact on world trade relations. The two biggest trading blocs - together they account for $30 \%$ of world trade though their mutual trade that the TTIP will address is considerably less at $6 \%$ - would negotiate to reduce both tariff and non-tariff barriers and ensure the best possible protection of mutual investment.

The background to the TTIP includes the stalling of the Doha Round of multilateral negotiations over several years because of strong disagreements between developing and rich countries, and the simultaneous rapid expansion of bilateral trade agreements. After previous multilateral agreements, tariffs are now so low that there is little benefit to be gained from further lowering them, and the TTIP has focused in particular on differences in regulations, which are seen as 'Non-Tariff Barriers' to trade and foreign investment. ${ }^{1}$ These have been portrayed as major obstacles to trade and to the economic growth that would result. Also, it has been argued that a partnership between the US and the EU could reassert the ascendancy of the world's richest countries in the politics of international trade, and the agreement could set a model for trade agreements in the world as a whole. ${ }^{2}$

The economic gains would come from firms no longer having to comply with two sets of regulations, which is a waste. Changing this would reduce exporters' costs, reduce prices, and increase trade, growth and productivity. ${ }^{3}$

For the EU the TTIP has been presented as an important step in finally restoring growth after the 2008 crisis. Enthusiastic advocacy was backed by studies said to show substantial benefits for GDP and in one case employment creation. Hopes were expressed for a quick and successful conclusion to negotiations to help put the crisis behind us.

1. The term Non-Tariff Barrier (NTB) is used by many authors. The Ecorys study (Berden $e t$ al. 2009) uses the term Non-Tariff Measure (NTM). Both are therefore used in this paper.

2. Cf the final report of the US-EU High Level Working Group (HLWG 2013). This has served as the template for what is to be negotiated.

3. Francois et al. (2013: 2, 110-11). 
The process of negotiation is largely kept from public view. Thanks to various leaks on the content of negotiation, the background has become slightly more open, with some information on the themes under discussion, albeit with little serious detail on the progress that may be made. With regulations being central to the negotiation, there is considerable interest in what the outcome might be as well as the negotiating process that is to agree on these.

While the differences in regulations across the Atlantic are seen as a barrier to trade and investment - because they add costs for exporters - and overcoming this as the key way to economic benefits from the TTIP, at the same time, however, the regulations involved cover most aspects of people's lives and the environment, and have major implications for the future. They affect health, food safety and quality, climate change, other environmental aspects, consumer safety, work, and several other areas. ${ }^{4}$ Regulations also have complex effects on businesses, both adding to their costs and reducing them (e.g. reducing the need for inspection of inputs, lessening costs of litigation over harmful products or processes, reducing impacts of flooding). They also affect the incentives for the directions in which business innovates (e.g. in resourcesaving and less polluting processes or safer products). As a result of such major effects, changes in regulations on these issues need to be taken into account too when making an assessment of the TTIP's impact, both when the assessment is done in economic terms or takes a broader approach.

Though the TTIP in some respects is to follow that of previous trade agreements, with sectoral and thematic chapters, it has some major innovations. These are especially on how regulatory differences (as barriers to trade) are to be addressed, the institutions to do so, and the overriding legal priority of the decisions that would result from these.

It has been proposed that a permanent body with regulatory responsibility ('competences'), comprised of top regulators and trade officials from both sides and supported by a number of working groups, would examine both existing and new regulations for their impact on transatlantic trade and investment. There are also proposals on how this must be done. ${ }^{5}$ From the information so far available, it seems there is likely to be little democratic participation in, or even oversight of, its activities. We consider the implications both for regulations and for their impact.

While regulations concern the whole of society, there is some information on which sections of society have been best placed to influence the negotiations on them. In response to a formal access to documents request, the European Commission revealed that up to April 2013, 119 of the consultation meetings in the preparation of TTIP had been with business representatives, and just 8 in total with consumer organizations, trade unions or other civil society groups

4. Annex I lists several of the most important regulations identified as priorities to be addressed in the TTIP from a business perspective.

5. European Commission (2013c). 
such as environmental or public health NGOs. ${ }^{6}$ This is significant for the likely course of negotiations because, as will be discussed below, the overall agenda from large business in particular in relation to alignment of regulations is likely to be towards their levelling downwards.

This paper considers first the main economic impact studies that analyse what the effects of the TTIP would be, their findings and how those are presented, and how they arrive at the results. These studies focus especially on the effects of lessening the regulatory differences across the Atlantic over a wide range of regulations. In Part II, we go on to discuss some aspects that are missing from those studies, most notably the benefits of regulations, and the major difference that it potentially could make to the overall assessment were the effects on those to be taken into account. Because regulations are central to the TTIP we devote considerable attention to working out how they may be affected by the approaches proposed for the TTIP.

6. http://corporateeurope.org/trade/2013/o9/european-commission-preparing-eu-us-tradetalks-119-meetings-industry-lobbyists 


\section{Part I The view of the TTIP economic impact studies}

\section{Introduction to the studies}

The most highly profiled studies of the economic benefits of TTIP that have been used and quoted as its rationale are first considered. We look at two groups of these, with some similarities in approach though also considerable differences. The first set of studies starts from a detailed empirical investigation to assess the scale of existing barriers and culminates in the widely quoted study from the Centre for Economic Policy Research (Berden et al. 2009, Francois et al. 2013), both commissioned by the European Commission. The second is composed of studies commissioned by the German government and the Bertelsmann Foundation (esp Felbermayr, Larch et al. 2013) which assess the effects of removing barriers without attempting an examination of the barriers themselves.

The studies use complex economic models or statistics and arrive at apparently precise and definite results, even if a more detailed examination of the reports may sometimes indicate strong qualifications. The application of such models can appear to give very strong scientific support for policy choices. However, the reliability of claims derived from them depends on the strength of the data, the appropriateness of the theory used and the assumptions or guesses and estimates made along the way (for assessment of trade models of the kind used in almost all the studies for the TTIP cf Taylor and von Arnim 2006). The examination here finds that there are grounds for doubting the significance of many of the overall benefits most prominently mentioned in public discussion of the TTIP. ${ }^{7}$

The presentation of the results of the studies is itself an important issue in this context as it has sometimes not reflected accurately the full findings that can be seen when the reports are examined more closely. Perhaps the most common are giving a predicted increase in exports without the corresponding increase in imports, or an increase in employment without the corresponding losses in employment from such a trade deal.

A more specific example is in the European Council's statement of 14 June 2013 (http://trade.ec.europa.eu/doclib/press/index.cfm?id=918), that 'Overall, the extra ... trade ... would mean an additional $€ 220$ billion ... worth of sales of

7. For a detailed technical assessment of the impact studies, see Raza et al. (2014). 
goods and services for EU based producers'. This omits the simultaneous increase in imports, which would be larger than this at $€ 226$ billion, according to the same study, leading to a net trade deficit from the TTIP (Francois et al, 2013, Table 21). ${ }^{8}$ The Council statement also says that 'our economy would be boosted by $0.5 \%$ to $1 \%$ of GDP, or $€ 119$ billion annually'. The figure given by the study on which this is based is $0.48 \%$, which can be rounded to $0.5 \%$, and this is the figure from the maximal scenario; the $1 \%$ figure does not appear in the study. Also, some accounts appear to give the impression that each year this figure of $0.5 \%$ is added to GDP, as if this was an addition to the growth rate; in fact, the increase in growth rate from the report is $0.05 \%$ on average annually for a period of 10 years.

\section{CEPR and Ecorys impact studies and their findings}

The estimated effects quoted by the European Council follow from studies done for the Commission by Ecorys and CEPR (Berden et al. 2009; Francois et al. 2013). Following a brief introduction to these, we look more closely at the most highly profiled results, those from the CEPR study.

These studies, complementary to each other, used a series of steps to arrive at the results. First, the height of the non-tariff barriers is estimated, i.e. the extent to which differences in regulations between countries and across the Atlantic are seen as obstacles by exporters. This was done in the Ecorys study by a survey of firms. The firms chose a number of between 1 and 100 and the figures were averaged per sector. Second, these figures were converted into the amount by which the barriers increase trading costs, by econometric estimation which attempted to separate out other factors that affect trade such as national income levels, geographical distance and language (using 'gravity equations'), also done by Ecorys. Third, the Ecorys study used experts to estimate how much the non-tariff barriers could be reduced if the political will were there. Finally, the results from the second and third steps were fed by the CEPR into a very large model (a computable general equilibrium or CGE model), which resulted in the findings on exports GDP and other variables, discussed below. This last step involved a range of assumptions and insertion of empirical estimates into the model.

Among the most important assumptions were the scenarios. The CEPR study's most widely quoted results are from its most optimistic scenario, called 'Ambitious', which is a 25\% reduction in non-tariff barriers facing exporters to the other side of the Atlantic. Although this does not sound large, the Ecorys survey results show that it is half the level of NTBs facing firms exporting to other countries within the EU (Berden et al. 2009, Annex 6, Table VI.o.1). Hence this scenario assumes that the US will be half-way to becoming an embedded member of the EU, within 10 years (and perhaps the EU of

8. The overall gain in GDP would come from an increase in productivity; see below. 
NAFTA). ${ }^{9}$ With the considerable differences in the basic approaches to regulation in major areas and to technical standards, this appears highly ambitious.

The general equilibrium model allows quite a long time period for effects to be felt, in this case 10 years, and does not delve in detail into the adjustment process between the start and the finish. An economy in equilibrium is assumed, including full employment, both at the start and the finish. It does not examine costs that may be associated with job displacement as activities rise or fall on the two sides of the Atlantic. The key issue in the models is the increase in trade associated with lower prices leading to higher output across the two trading blocks (and in their interaction with the rest of the world).

\subsection{The TTIP outcomes in the CEPR/Ecorys studies}

The TTIP outcomes from the CEPR study have played a major role in the debate on the TTIP so it is worthwhile to look at them more closely. The estimated outcomes are examined here especially for the CEPR's maximum or 'Ambitious' scenario which is seen by the European Commission as the upper bound of the potential range of effects from the TTIP (European Commission 2013a: 28). After identifying the key scenarios, the following paragraphs then look in turn at the estimated effects for trade, growth, income, employment, wages, job displacement, sustainability effects and foreign direct investment, with some brief comments.

In the Ambitious scenario the level of NTBs are reduced by half of all 'actionable' NTBs. At the same time, $100 \%$ of the generally very low tariffs are assumed to go, as are 50\% of public procurement NTBs which are seen as having a relatively small effect on trade. The 'Less Ambitious' scenario removes $20 \%$ of 'actionable' NTBs and $25 \%$ of public procurement NTBs. 'Actionable' NTBs are all those that can be reduced or eliminated if the political will is there.

For trade the Ambitious scenario showed an increase in exports from the EU to the US of $28 \%$, and to the world as a whole of $5.9 \%$. As it becomes relatively less expensive to export to the US compared to other EU countries, a significant portion of the increase to the US is trade diverted from what was previously trade between countries within the EU. ${ }^{10}$ Importantly, they also find that the corresponding increase in imports to the EU from the US and the world as a whole is actually larger than the increase in exports. The EU gains in total, due to reduced prices, but the amount is very small. The same is true for the US. ${ }^{11}$

9. If we make the crude assumption that NTBs facing exporters within NAFTA are the same as those within the EU.

10. Francois et al. (2013: 54-55).

11. The lower gains from trade liberalisation as measured by computable general equilibrium models, of the type used to analyse the TTIP impact by CEPR and others, compared to earlier findings with such models are discussed by Ackerman and Gallagher (2008). 
In relation to growth the CEPR concludes that the impact on EU GDP would be $0.48 \%$ after 10 years, in its Ambitious scenario. In terms of increasing the growth rate, this means $0.048 \%$ per annum over those 10 years after which it would cease. This is an increase of one-twentieth of one per cent in growth rate for that period. The corresponding figure for the US is a $0.040 \%$ increase, smaller again. The Less Ambitious scenario leads to a $0.27 \%$ increase in GDP after 10 years; the figure for the USA is $0.21 \%$. Compared to the effects of austerity policy, the contribution to getting out of the crisis would be miniscule.

The CEPR report produces estimates of changes in disposable income, amounting to an increase of ' $€ 545$ per year for a family of four' in the EU. However, it appears that this is not derived from statistical data on families of four but rather by calculating the average figure per person and then multiplying it by four to get the 'family of four'. Using the per capita figures gives a benefit of $€ 2.61$ per week per person for the Ambitious scenario or $€ 1.47$ for the more likely Less Ambitious one. In both cases it amounts to the price of a cup of coffee per person per week. Approximately similar figures are obtained for the USA.

In the case of employment the model is built on the assumption of full employment so that any economic gains are in the form of increases in wages rather than increased employment (see Francois et al, 2013: 71). Other implications of this full employment assumption are indicated below when considering job dislocation.

For wages, the study estimates they will increase at approximately the same rate as GDP, that wages will keep pace with productivity changes and that the shares of wages and profits in GDP remain the same. This would be very much out of line with the 30 years before the crisis, when labour's share of GDP in Europe (EU-15 countries) declined sharply from 67\% in mid-70s to $57 \%$ pre-crisis (2007). Moreover the TTIP, by improving freedom of movement for direct investment - one of the direct objectives of the planned treaty - could be expected further to strengthen the bargaining power of mobile factors (e.g. finance or MNCs) relative to much more immobile ones (notably most types of labour). This would be likely further to depress the share of wages and salaries below that of productivity. In addition, the high level of unemployment that is likely to continue if current crisis policies are maintained would act very much in the same direction.

For job displacement, the CEPR study finds that $0.65 \%$ of people employed would be displaced which it describes as 'minimal' in comparison with normal job turnover (Francois et al. 2013: 78) and implies there would be little problem since people would change jobs by being pulled to other jobs with higher wages. However, the study does not address geographical displacement, where due to the import increase employment may be lost in, for example, a high-wage region of Europe and the exports expand from a region with significantly lower wages and conditions; this is likely to result in unemployment that could be of significant duration. 
Also, the analysis only addresses inter-industry job change, where people switch industries (p. 77). However, the figures in the CEPR study itself show that this kind of trade amounts to only $20 \%$ of the increase in trade from the TTIP. The other $80 \%$ would be in the form of intra-industry trade (i.e. where both exports and imports in the same sector increase) and would imply further displacement. ${ }^{12}$ A higher level of job displacement than is taken into account in the study and potentially significant transition periods between jobs seem likely due to a combination of these aspects, and the difficulties would be aggravated considerably in a context of likely high unemployment if the current austerity policies continue ${ }^{13}$.

The sub-sections on environmental effects are extremely brief, with the conclusion that TTIP will have "negligible effects on $\mathrm{CO} 2$ emissions and on the sustainable use of natural resources' (p. vii). From the minimal information given, the $\mathrm{CO} 2$ estimates are based in part on changes in physical transport from the agreement due notably to trade, and for both issues the reasoning is given that 'improved productivity' will reduce the need for 'primary inputs' (p. 3). An optimistic future for emissions trading is foreseen, reducing the $\mathrm{CO}_{2}$ effect even further. However, there is no sign that the analysis takes into account any effects of the potential changes in regulations on the environment due to the TTIP discussed in Section 1 of Part II below, and the potentially much larger effects involved.

A separate analysis is carried out within the study on the quantitative effects of removing NTB barriers to foreign direct investment (FDI), on changes in FDI profits, the number of affiliates (in the host country or region) and employment. The result is a $9.4 \%$ increase in employment by US affiliates in Europe, and $10.9 \%$ by European affiliates in the US. There would also be an increase in profits of EU firms in the US of $€ 10.3$ billion (p. 92-3). However, unlike the rest of the analysis in the study, these estimates are derived from partial analyses which do not take into account some important effects. Notably, they omit substitution effects, how the increased economic activity that is calculated displaces other activities.

These are crucial because FDI is an alternative to exports for serving foreign markets. If new FDI is for this purpose, which typically it is likely to be under the TTIP, that would normally reduce exports to the host region/country. Conversely, reduction of NTBs would make it easier for US firms to serve the European market by exports from the US - indeed that is the express purpose of TTIP. This effect would tend to reduce employment in US MNCs in Europe. The same would apply for European firms in relation to the USA. Overall, this form of partial analysis, by leaving out key effects, is likely to overstate the total positive effects of FDI in aggregate.

12. The empirical research findings on the role of inter-industry compared to intra-industry trade on labour market adjustment appear to be contradictory with different studies finding the effect of one or the other to be greater (Derbel et al. 2013: 3).

13. See also Raza et al. (2014: Section III), for a similar conclusion, and for development of the issues concerning adjustment policies including labour and social policies. The assumption made by the study of full employment at all times bypasses these questions. 


\section{The Ifo impact studies}

A somewhat different approach was used in the other group of studies, produced firstly by the Munich-based economic research group Ifo and then for a wider audience in cooperation with the Bertelsmann Foundation. ${ }^{14}$

This series of studies begins by trying to identify the average effect on trade of existing preferential trade agreements (PTAs); a large number of these have been concluded in recent decades between a wide variety of countries. It is assumed that the TTIP will have the same average effect on trade. ${ }^{15}$ It does this by a statistical analysis of existing bilateral trade between 126 countries in a single year. Then, after taking account of the effect on trade costs and trade flows between the countries that will be directly involved in TTIP and those that will be indirectly affected by forms of trade diversion, they arrive at the conclusion that trade between EU member states and the United States will grow by an average of 76 percent. A simple one-sector model of economies is then used to study the effects on outcomes such as growth and employment.

Ifo does not examine the particular 'non-tariff barriers', the details of the economies or the features of the TTIP.

Two very basic questions arise about this method when applied to the likely effects of the TTIP. The first is whether the assumption that the trade effects from TTIP will be the same as the average increase in trade from existing preferential trade agreements around the world is adequate. This appears questionable in view of the unique nature of the proposed TTIP and the close economic integration already established between many sectors of the economies, including the major role of multinational companies established for a long time on both sides of the Atlantic. The second, related to this, is the question of whether a simple, one-sector model of economies is adequate to analyse the effects of the TTIP. It means not addressing the structures of each economy, the different sectors, or how these may be differentially affected by TTIP, points given considerable consideration in the CEPR/Ecorys studies.

14. These included a report for the German Ministry of Economic Affairs (January 2013) and derivative summaries including a large part of the Bertelsmann/Ifo 'Macroeconomic effects' report. A further working paper appeared in October 2014, which focuses especially on the real income gains employing 'a similar setup' to the Ministry study. All these are listed in the bibliography under teams led by Felbermayr. The October 2014 paper (Felbermayr et al. 2014) has more countries (173 compared to 126 previously) and later data (2012 compared to 2007). It also contains additional clarification of the overall approach. An English summary of the Ministry report, originally in German (Felbermayr, Larch et al. 2013) is also available and is included in the references as Felbermayr and Larch (2013). For shorthand we refer to the large study as the Ministry study and the other as Bertelsmann/Ifo or Bertelsmann.

15. Trade is the average of exports and imports in these studies. Preferential trade agreements are between two or more countries and give privileged access to each others' markets considered in a very wide sense; in most cases though not by no means all they are 'deeper' agreements that include aspects of regulations, though the legal enforceability varies widely (for further information see WTO 2011). 


\subsection{The Ifo results}

The main and most developed study, of 160 pages, produced for the Ministry of Economic Affairs in Germany (Felbermayr, Larch et al. 2013), is the basic analysis behind most of the Bertelsmann 'Macroeconomic' report which has gained the most publicity. We discuss the results from the preferred scenario of the main study, which is the assumption that there will be a $76 \%$ average increase in transatlantic trade; this scenario is also the one used in the Bertelsmann/Ifo report. In order to calculate the impacts of this scenario on features like growth and employment, the Ministry study uses the most developed form of the model employed in that study. ${ }^{16}$ We focus here particularly on the findings that have been given most prominence, those on real income or GDP growth as well as employment, and briefly address trade also.

Growth of GDP for the EU27 would increase by $1.65 \%$ in real terms and the US by $2.1 \%$ over the $10-20$ years which the changes would take to have an effect. Taking the mid-point (15 years), this means an approximately $0.1 \%$ increase in GDP per annum in both cases, one-tenth of one per cent. This is close to that found by the CEPR study and also minute. ${ }^{17}$

For employment, it finds the increase in the EU over the period would be 124,000 and in the US, 69,000. There would be a fall in employment in the rest of the world of 165,000 , resulting in an overall employment increase in the world as a whole of $28,000 .{ }^{18}$ This is an average increase in employment of 8,000 per year for the EU and 5,00o for the US. Compared to the total EU unemployment of 24.5 million, the effects again are tiny.

So the preferred scenario, used with the most developed form of the model, gives very low impacts indeed from the TTIP, for both growth and employment.

The Bertelsmann report, and another section of the Ministry report, give very different results, both for growth and employment. We discuss these in turn.

\subsubsection{The higher findings for real incomes or GDP growth ${ }^{19}$}

The Bertelsmann study gives figures for the growth of incomes/GDP that are much higher than those quoted above; these are reproduced from another

16. This adds two features 'at crucial points' to a simpler version of the model also used. The two additions are modelling of the effect of differences in productivity among firms, and 'search unemployment'; it clearly regards the extended model as superior. (Felbermayr, Larch et al. 2013 p. 83; own translation).

17. The more precise figures are $0.11 \%$ for the $\mathrm{EU}$ and $0.14 \%$ for the US. Source: Ifo Ministry study table III.12; own calculation.

18. They also give figures for Germany, which would have an increase of 25,000 , or 1,700 per year.

19. This is real incomes or real GDP in the studies, and these are used interchangeably below. It is also referred to as 'welfare' there. Due to a feature of the model used - that the entire economy is a single sector - real GDP growth is the same as growth in 'welfare' or 'equivalent variation' (Felbermayr et al. 2014: 14). 
section of the Ministry study. The US would have an average real income increase of $13.4 \%$ from the TTIP, and in the EU there would be particularly high results for the UK (9.7\%), Sweden (7.3\%) and 6.6\% for Spain. The EU average is $5.2 \%$. The world as a whole would gain by $3.3 \%{ }^{20}$ We discuss five issues about these findings.

First, a later analysis of this issue by broadly the same authors (Felbermayr et al. 2014) gave considerably lower figures for the three countries with the highest increases above and for the world as a whole, approximately a third to a half of these (Felbermayr et al., 2014, Table 5). We consider this further below.

Second, the Bertelsmann/Ifo report's results are also much higher than those obtained by the original authors of the much-cited paper whose approach it follows (Arkolakis et al. 2012), and who applied it to a major change in US trade, as well as by another author who applied it to China's trade liberalisation (Leromain 2013). The result for the US was approximately a 1\% change in real income following a $100 \%$ change in total US trade. ${ }^{21}$ The China study found a gain in real incomes of half a per cent from the dramatic increase in trade over the period 1995-2009. ${ }^{22}$

Third, the Ifo authors appear to use, at least in the later paper, a method of calculation of the Arkolakis et al formula (for the relation between income and trade change) that gives considerably higher results than the original, typically 2 to 4 times higher, by using GDP instead of gross output. ${ }^{23}$ The Ifo authors point out in another paper that using this 'lead[s] to overestimation of welfare gains' (Felbermayr, Jung and Larch 2013: 18-19). If we follow Arkolakis et al and substitute gross output for GDP and re-calculate the real income change in the later paper, we get the results in table 1 . They are now much smaller, ranging from less than $1 \%$ to $2.4 \%$, very different from the results in Bertelsmann/Ifo but also similar to the much lower results in the Ministry report given above for the preferred scenario. ${ }^{24}$

20. The EU figures are weighted by country GDP; own calculation. Average for the world: Ministry study table A.II.6.

21. Arkolakis et al. (2012: 95). This was for a change in imports from their current value to zero. Approximately the same result is found if we apply the method to a doubling of US trade. The brief discussion of the use of Arkolakis et al. in the Bertelsmann/Ifo paper is on p. 12. In Felbermayr et al. (2014) it is referred to on p. 25.

22. Leromain, 2013. With this approach when imports take up a greater share of the domestic market, income/GDP increases. As the China figures show, it also has the curious effect of declining incomes if domestic supply increases its share, as it did in certain sub-periods, despite the huge increase in GDP as conventionally measured.

23. Judging from the figures for the US and Spain on p. 25 of the Felbermayr et al. (2014) paper and Table 5, col. 1, they appear to use trade/GDP instead of trade/gross output that Arkolakis et al. use. Own calculation.

24. Following Arkolakis et al we use gross output instead of GDP in the figures, and assume the same proportional increase in trade as in Felbermayr et al. 2014, which can be calculated from the figures there. Those countries which have the largest trade increases in the Bertelsmann report as well as the larger EU economies are included in the table. 
Table 1 Real income/GDP effect from TTIP: Comparing results in Bertelsmann/Ifo with Felbermayr et al. (2014) and gross output substituted for GDP

\begin{tabular}{|c|c|c|}
\hline & Bertelsmann/Ifo & $\begin{array}{l}\text { Felbermayr et al. 2014, } \\
\text { substituting gross output for GDP }\end{array}$ \\
\hline United States & $13.4 \%$ & $2.4 \%$ \\
\hline United Kingdom & $9.7 \%$ & $2.2 \%$ \\
\hline Sweden & $7.3 \%$ & $1.7 \%$ \\
\hline Ireland & $6.9 \%$ & $1.4 \%$ \\
\hline Spain* & $6.6 \%$ & $2.1 \%$ \\
\hline Greece & $5.1 \%$ & $2.3 \%$ \\
\hline Portugal & $5.0 \%$ & $1.8 \%$ \\
\hline Italy & $4.9 \%$ & $1.5 \%$ \\
\hline Germany & $4.7 \%$ & $1.3 \%$ \\
\hline Netherlands* & $4.4 \%$ & $0.4 \%$ \\
\hline Poland & $3.7 \%$ & $1.2 \%$ \\
\hline France & $2.6 \%$ & $1.6 \%$ \\
\hline
\end{tabular}

Note: For Spain and Netherlands there are no gross output data in Eurostat; it is assumed that it is 2 times GDP, i.e. very similar to the other countries.

Sources: Col. 2: Bertelsmann/Ifo and Ministry table A.II.6. Col. 3: Felbermayr et al. (2014: table A1), Eurostat inputoutput tables naio_cp17_r2, US Bureau of Economic Analysis. Own calculations.

Fourth, only through enormous increases in trade do the larger welfare increases result, as we can see both from a direct statement in the 2014 paper itself and from using the Arkolakis et al formula that applies there. The 2014 paper states that the US goes from $12 \%$ to $37 \%$ ratio of trade to GDP, and using the same formula we can see the UK goes from $23 \%$ to $48 \%$ and Greece from $19 \%$ to $39 \% .{ }^{25}$ The corresponding figures for the Bertelsmann report appear to be even higher for these countries, we can calculate. These results appear to be a long way from a realistic assessment. Arguably, for trade to triple as a share of GDP in the large complex continental economy that is the US would imply such a massive transformation that it could hardly be more unrealistic.

Fifth, the European Commission itself stated that the Ifo results are unrealistically high, pointing to the very high figure given for the US real GDP/income growth and comparing it to the much lower figure that is the US's 'proportion of GDP that is affected by trade with the EU,. ${ }^{26}$ We can see other examples, such as an increase in UK real GDP of 9.7\% despite exports to the US amounting to just $2.6 \%$ of GDP. Similarly for Spain (7\% increase in real GDP, exports to the US $0.6 \%$ of GDP) ${ }^{27}$ For Greece the respective figures are $5 \%$ and $0.3 \%$, and Poland $4 \%$ and $0.6 \%$. The general point here is the same as that made by the Commission: is it likely that such a small amount of trade

25. The US figures are on p. 25. UK and Greece are calculated here using the figures in table A1.

26. European Commission, 'TTIP: The Economic Analysis Explained', September 2013. It gives a figure of $3.5 \%$ for the proportion of US GDP that is so affected.

27. Felbermayr, Heid and Lehwald (2013: Fig. 5). Exports and GDP: UN Comtrade and OECD respectively. 
with the US could have such a large effect on GDP? The difference is around 10 times in some cases. Is it likely that even a tripling of trade - i.e. of both exports and imports - would have such an effect?

In sum, the Ministry report using the preferred scenario gave very low results for change in real GDP/incomes and close to those of the CEPR, and the higher results in the Bertelsmann report appear very problematic on a number of grounds. ${ }^{28}$

\subsubsection{The higher findings for employment}

The Bertelsmann/Ifo report attracted a great deal of attention for predictions of substantial increases in employment, with figures more than ten times greater than in the Ministry study's preferred scenario: 1,350,000 for the EU and 1,086,000 for the US. This model uses one of the two features that the more developed model in the Ministry study used but not the other. It is based on a previous paper by some of the authors, though with a change in a central assumption. Some questions arise about this analysis.

The original paper was concerned with OECD countries only, i.e. the richer countries of the world. It estimated that the average increase in trade for these countries from preferential trade agreements was $36 \%$, and then used this figure to calculate the employment effects of an average PTA for those countries. The Bertelsmann report appears to have increased this trade effect very substantially before using it to arrive at the effects of a transatlantic agreement. It is said that this would 'ensure comparability of results' with those in the rest of the Bertelsmann report (p. 34), though the work on employment in the Bertelsmann report concerned the same OECD countries. ${ }^{29}$

The Ifo Ministry study expressly argued against an earlier study that found much higher employment results from a potential preferential trade deal between the US and EU. As it happens, the study they criticise arrived at slightly lower results than the Bertelsmann/Ifo study. ${ }^{30}$ The Ministry study argues that its method, which led to the far lower forecasts of employment creation given above, was distinctly superior thanks to the inclusion of an additional feature in its model that enabled it to take better account of jobs lost

28. It does not seem that the different levels of aggregation used in obtaining the low as opposed to the high results is likely to explain the difference for the EU, if we judge from the work of the authors themselves who examined this issue for the case of the TTIP in the 2014 paper (p. 37-8). They found that the higher level of aggregation gives higher results for the EU, largely because it does not include the trade diversion (reductions) within the EU. The Ministry study used such a higher level of aggregation but obtained low results, whereas the opposite would be the case if the aggregation could explain those low results.

29. It says that 'the same aggregated trade creation effects between the EU and USA are [used] ... as in the model with the 126 countries' (Bertelsmann/Ifo, top of p. 34). Apart from this, the employment analysis in Bertelsmann/Ifo is otherwise based on the original Heid and Larch (2013) paper (Bertelsmann/Ifo n. 20). In that paper they use the PTA coefficient of 0.311 found for the OECD countries (column 6 of table 11, see p. 23), which is equivalent to a $36 \%$ increase in trade as they once again explain in $n .16$ of that paper. The same 28 OECD countries are included in both.

3o. Vandenbussche, Wooton and Venables (2002). 
as well as those gained. The same issue would appear to arise in relation to the Bertelsmann study employment analysis, which lacks this feature. Both Raza et al. and Stephan argue that this difference leads to the higher figure obtained in the Bertelsmann report. ${ }^{31}$

\subsubsection{Trade}

As we have seen, the approach of most of the Ifo impact analysis is to assume that trade between US, on the one hand, and EU on the other, will increase sharply. However, due to price changes associated with this and related income effects, there are other trade effects, both trade substitution and creation, notably with previous trade between EU partners now being diverted to across the Atlantic, and also affecting trade with third countries.

The Bertelsmann/Ifo report applies the percentage changes from the Ministry report to the actual export values. However the crucial figure - the overall effect on trade for particular countries or the EU - is curiously not given there or in the Ministry report. A close estimate of these can nevertheless be put together from data in the Ministry study supplemented by trade statistics. ${ }^{32}$ The results are somewhat odd.

While showing strong percentage increases in trade in both directions across the Atlantic, those figures also point to substantial falls in trade for all the major EU trading countries, including with each other, to a degree that appears implausible. Remarkably, the substantial increase in trade with the US is outweighed nearly three times by the fall in overall trade for these countries, ending up with a decline of over $\$ 400$ billion in total for the countries.

To conclude, the Ifo findings are that there would be extremely small effects from the TTIP - both for real GDP/incomes and employment - in the main study for the Ministry of Economic Affairs under its preferred scenario. A different analysis which gives larger effects for real incomes/GDP and is reproduced in the Bertelsmann/Ifo report appears to be implausible and otherwise problematic on various counts. The larger employment effects given in the Bertelsmann report are problematic as well.

31. Raza et al. (2014: 12-13) and Stephan (2014). Raza et al. add that use of 2010 data in Bertelsmann/Ifo, i.e. at a time when unemployment was higher due to the crisis, instead of 2007, also accounts for part of the difference. The feature concerned is the differential productivity between firms (the Melitz model), where with increasing trade, more productive firms push out those that are less productive.

32. The Ministry study contains a table in matrix form showing the change in exports and imports among 25 of the largest trading countries in the world including the BRICS (Table A.III.1). All the major trading countries of the EU are included. As was done in the Bertelsmann report, the trade values are obtained here by applying the percentage changes in this table from the Ministry study, to the international trade data from the UN (Comtrade) for 2010. A sample of the results can be seen in the Bertelsmann report table 6, where there is to be a fall in trade between the UK and all the countries with the exception of the USA, a fall that is in most cases very large. 


\section{Part II A closer look at regulations in relation to the TTIP}

We shift focus now to a closer and hopefully more realistic consideration of regulations, and the potential consequences that the TTIP might have for these.

\section{Transatlantic differences in regulations and how the TTIP proposes to deal with these}

To get a better appreciation of the issues involved, we briefly examine the approach the TTIP is to use to deal with the differences in regulations across the Atlantic, and then go on to look more closely at what these differences actually are and their significance for the TTIP. We do not yet discuss the institutions and procedures to be established by the TTIP and their significance; these are examined in some detail in Section 2.

The key assumption behind the arguments for TTIP is that substantial gains can be made by increasing the compatibility of regulations and regulatory regimes between the EU and the USA (HLWG 2013). The scope for doing this is said to exist because of a number of incompatibilities that are judged to be unnecessary. At the simplest level, there is duplication on both sides of the Atlantic of administration or paperwork that is performed differently but has the same purpose. There are more substantial cases that involve procedures that have the same functional result, such as different safety tests, giving effectively the same degree of safety. A frequently-quoted example is the need for slightly different crash tests for cars, meaning that the exercise has to be repeated to comply with two sets of rules. This is a waste of resources for exporters and adds to their costs. Eliminating these costs will increase trade, productivity and growth.

However, alongside regulations that are essentially duplications of this kind there are many that have significantly different levels or standards on one or other side of the Atlantic, levels of safety, health or financial regulations for example. TTIP proposes three forms of action to achieve regulatory compatibility: harmonisation of the standards and tests from both sides of the Atlantic (for future regulations), and either recognition of equivalence or mutual recognition of those on the other side (for existing regulations). ${ }^{33}$ These have an important bearing on the likely effect of the agreement.

33. This is set out in the final report of the US-EU High Level Working Group, February 2013 (HLWG 2013). http://trade.ec.europa.eu/doclib/docs/2013/february/tradoc_150519.pdf According to a leading academic in the field, under mutual recognition, regulators retain 
Mutual recognition in particular, depending on how it is done and what the regulations are, could lead to different levels of regulation competing with each other. Under such circumstances regulatory arbitrage may occur, with companies moving their operations to a lower level of regulation, supplying other locations from there and undermining the higher level of regulations, as in the example of the financial sector in the pre-crisis period (Roubini and Mihm 2011). As a large portion of the trade is carried on by multinational corporations already present on both sides of the Atlantic, this should not be difficult to do. Whereas the EU Treaty contains a provision to prevent a race to the bottom between member states in regulation, and conformity to EU standards also limits this, from the information available no such provision appears to have been put forward for the TTIP to prevent it. ${ }^{34}$

Achieving 'compatibility' between two different sets of regulations could lead to different outcomes, which could vary by the area concerned. These include acceptance by one side of regulations or the regulatory system from the other side. However, while 'levelling up' has been mentioned as a possibility for the agreement, where higher standards such as the precautionary principle ${ }^{35}$ or labour rights are accepted on the other side, the political realities to date would seem to make this highly unlikely in the most important areas. In no case of the examples of priority 'non-tariff measures' for the TTIP listed from the Ecorys report in the Annex below does such an approach appear to be the case.

An indication of some of the regulations (Non-Tariff Measures or Barriers) considered as priorities to be addressed in the transatlantic deal from a business point of view can be seen from the Annex. ${ }^{36}$ The items selected there from the priority lists in the Ecorys report all concern issues where standards

separate standards for internally-produced products, but agree to recognize the other jurisdiction's standards for products imported from it (Shaffer 2002). The exporting country has the responsibility to see that the products or services conform to the regulations. The HLWG report also leaves space for 'other agreed means' for this (p. 3-4). The term 'mutual reliance' was added in this context, notably to address the issue of each other's inspections in the pharmaceutical and medical devices sector and reliance on each other's regulatory regimes in the financial services, as in the statement to European Parliament INTA hearing on the regulatory part of TTIP on 14 October 2013 by I. Garcia Bercero, http://www.europarl.europa.eu/document/activities/cont/201310/20131023 ATT73264/20131023ATT73264EN.pdf.

34. The EU Treaty states that the EU will take as a base 'a high level of protection' in health, safety, environmental protection and consumer protection (TFEU Art. 114.3); Pelkmans says that this article was intended to prevent a race to the bottom in the internal market (Pelkmans 2012: 17). The extent to which this is actually effective in various areas could be debated. However, conformity to common EU standards is often a requirement and this maintains a certain floor for most products. For general discussion of these issues and of mutual recognition in the context of the EU cf European Journal of Public Policy, special issue, 14(5), August 2007.

35. This means that where from the available scientific information danger to environment or health are assessed to exist, action can be taken before the effects become fully apparent. The position taken under the precautionary principle is provisional until further scientific information becomes available that may clarify the risks. Cf von Schomberg (2013) who gives a detailed discussion of its application, especially in the EU.

36. Based on Ecorys' survey of firms, discussions with business associations, views of experts that worked on the NTMs and the literature which the experts also used. Unfortunately, no 
or levels of regulations differ between the two sides of the Atlantic, and sometimes quite strongly. They range for example from regulations for potentially toxic chemicals to regulations related to climate change, pricing of pharmaceuticals, labour regulations and food labelling.

We discuss in Section 2 below the potential outcome of the key regulatory institutions and processes to be established in the TTIP. They will face some major differences across the Atlantic in the content of regulations, in the means whereby they are decided and how they are enforced. The differences can be illustrated with reference to regulation systems for food and beverages and for chemicals, two sectors that are important for the TTIP according to the impact studies, as well as the broader issue of technical standards which affects a wide range of regulations.

In Food and Beverages, the basic approaches to food safety regulation are fundamentally different on the two sides. EU food safety legislation is based on the information flow along the food value chain for traceability of contamination while the US authorities focus on testing the final product. The Ecorys study concludes for this area that ' $[\mathrm{m}]$ any of the sector-specific NTMs are likely to remain, notably those related to health and consumer safety', and its discussion states more or less explicitly that a low or very low amount of the regulatory differences could be reduced (Berden et al. 2009: 89).

Regulation in the Chemicals sector faces similar problems. The basic approaches differ with the USA placing 'relatively greater reliance on selfregulation, ... the EU ... on the use of regulations' (ibid. p. 62). However, the highest priority item given for the TTIP by US firms and industry experts is the difference between the US Toxic Substances Control Act and the EU's $\mathrm{REACH}$, these being centrepieces of chemicals regulation on each side of the Atlantic. Unlike REACH, the TSCA has had very limited success in dealing with toxic chemicals, managing to ban just 5 chemicals or chemical families out of the 83,000 chemicals in the regulating institutions' database (cf GAO 2007, 2013; Gomez 2013) and has still not managed to ban asbestos. ${ }^{37}$ While there are discussions in the US about revising the TSCA to make it more effective, it seems clear that there is little prospect of moving in the direction of REACH in the foreseeable future (cf Gomez 2013).

Technical standards present a similar picture. These are very important in regulation because conformity with specific standards is a requirement for many regulations. There are basic differences between the US and the EU in

indication is given on the nature of the experts or the literature, but they too are likely to be largely associated with business associations and companies. Overall the views expressed are likely to be those of the companies.

37. 'It still is used today in automobile brakes and clutches, roofing shingles, cement piping, corrugated sheeting, vinyl tile, and other construction products. Many manufacturers are taking precautions to guard workers today against possible exposure, but many companies and people are not, still unaware to the dangers that exist.' http://www.hrreview.co.uk/ blogs/blogs-health-safety/tim-povtak-occupational-hazards-risk-of-asbestosexposure/44128. 
this area which appear very difficult to reconcile. The US system is primarily voluntary, private sector and market-place-driven, with competing standardsetting bodies developing standards that coexist. The EU has developed a centralised standard development system with clearer and more predictable links to legislation. 'In the US system, in the event that a relevant standard is not available, no transparent process is foreseen to connect the development of future standards and the regulatory work. ... Even more critically ... EU legislation refers to international standards, such as ISO and IEC, and corresponding US legislation refers instead to domestically developed standards by standard developing organisations claiming to be international.' (Alemanno 2014: 17-18; CEN/CENELEC 2013). While cooperation in standards between the EU and US has been promoted for quite a number of years, and a programme of mutual recognition of conformity tests for standards was undertaken, in general progress has been very difficult and in several cases stalled. ${ }^{38}$ There is a 'very low' adoption of international standards in the US compared to Europe, according to the Director General of CEN and CENELEC, two of the three European standards bodies (Santiago 2014).

Contrasting approaches to international agreements bring further and often major differences. The US Congress has always taken a fiercely independent position on such engagements and over the past hundred years has refused to ratify many international agreements that involve regulations that would constrain the US. The US has not ratified the most basic international agreements in chemicals such as the Stockholm Convention, ${ }^{39}$ has ratified only two of the eight ILO conventions which address issues such as forced labour and child labour, and according to one report would not participate in an internationally binding treaty in the next Climate Change Conference in Paris in $2015 .{ }^{40}$

As a clearer picture has emerged over time of the actual differences in regulation and regulatory regimes across the Atlantic, mutual recognition, which does not require equivalence of regulations, has been increasingly emphasised as the key means to deal with this, as in a 2014 report from the Konrad Adenauer Stiftung (Freytag et al. 2014: 12). A report to the European Parliament put a somewhat similar analysis to that given here of the implications of the differences in regulations (Bureau et al. 2014: section 4). ${ }^{41}$

38. The mutual recognition programme mentioned (beginning in 1997), in the key area of conformity assessment for standards, was initially to be a broader programme covering 11 areas, then limited to 6 in the agreement itself, of which 2 are regarded as having then succeeded (Shaffer 2002; European Commission 2013d).

39. The Stockholm Convention on Persistent Organic Pollutants (2001) agreed to ban nine of the twelve most dangerous of these chemicals ('chemical substances that persist in the environment, bio-accumulate through the food web, and pose a risk of causing adverse effects to human health and the environment') and to limit the use of DDT to malaria control.

40. 'Obama Pursuing Climate Accord in Lieu of Treaty', New York Times, August $26^{\text {th }}, 2014$

41. The study argues that if there was alignment of regulations in certain parts of the agro-food sector it could well lead to alignment with the lower level of regulation, or alternatively, if there were mutual recognition of different levels of regulation, the lower costs at the lower level of regulation were likely to push out the higher level of regulation (e.g. where there is a 
From this starting point, the task for the TTIP looks very difficult. The regulations and regulatory systems differ strongly between the EU and the USA in many important areas, from climate change and the environment to labour regulations, pharmaceutical pricing, food and chemicals, as well as broader technical standards processes. They very often embody different philosophies as well as political contexts and have been developed by different processes such that working out a common system that preserves existing levels of promotion of societal and individual well-being will be extremely difficult in quite a number of important fields.

Moreover, the approach from some industry associations and typical regulatory reform programmes has been to consider regulations mainly as barriers that carry costs and not as bringing benefits to society or as reducing costs to others. With their likely influence on the process (see below), the emphasis therefore from the start appears in effect to be towards reducing regulations. There are understandable fears that TTIP negotiations could merge with a more general agenda for deregulation and lead to the removal of important rules that have been established up to now. ${ }^{42}$

\section{Taking regulatory benefits into account in the TTIP}

The approach to regulations implicit in the impact studies is to treat them as costs for companies. Any diminution of regulatory differences between the US and the EU is analysed simply as a saving in trade costs for companies; no account is taken in their actual analysis of any benefit to companies or to society at large from regulations or how they might be affected by the TTIP. ${ }^{43}$ The analyses neglect tools widely used for assessing in economic terms the benefits of regulations alongside their costs. Such an approach has been described as arriving at a match, asking the score, and being told the number of goals scored by one team only. We look here first at the potential outcome for regulation in the TTIP, then at how regulation is treated within widely-used approaches to public policy where both the benefits and costs of regulations have been considered. This is followed by some specific examples.

higher level of animal welfare). This was a study of the agro-food sector but the same principle applies to a number of other sectors where standards are at substantially different levels across the Atlantic and where producers' costs are correspondingly different.

42. Cf. the EU REFIT programme (European Commission 2013e: 8), and the recent Stoiber Group final report (http://ec.europa.eu/smart-regulation/refit/admin_burden/docs/o810web_ce-brocuttingredtape_en.pdf)), as well as the Dissenting Opinion to this report (http://ec.europa.eu/smart-regulation/refit/admin_burden/docs/annex_12_en_hlg_ab_ dissenting opinion.pdf).

43. Instead, consideration of which differences in regulations can be reduced, and hence consideration of their benefits, are seen as political decisions, and so fall outside their analysis (Francois et al. 2013: 19). A more recent impact study of the TTIP by the same authors acknowledges that 'most NTBs are based on domestic regulations that address certain market failures' (Francois and Manchin 2014: 22), but there is still no analysis of the effect of those market failures. 


\subsection{What might be the regulatory outcome in TTIP?}

The ultimate effect of the TTIP on regulations depends not only on the regulations that are actually included in the agreement itself, but more so on the institutions and processes for future regulatory cooperation to be established under the TTIP as a 'living agreement'. ${ }^{44}$ The institutions proposed include notably a Regulatory Cooperation Council (RCC). This would include senior representatives of regulators, notably the Commission's Secretariat General and the US Office for Information and Regulatory Affairs (OIRA), as well as trade representatives, i.e. DG Trade and the Office of the US Trade Representative (USTR) (European Commission 2013c).

Of special importance for all this is the major innovation of the TTIP, that the constraints ("disciplines") to perform such regulatory cooperation, including the detailed processes for carrying this out, would be given legal force, apparently for the first time in the history of trade agreements (Alemanno 2014: 43 n.156), ${ }^{45}$ and the force would be that of an international treaty, which takes priority over domestic legislation once it has been voted into law by the parliaments. Another innovation is that the Regulatory Cooperation Council would be a permanent body (ibid p. 44).

With the overriding formal priority of increasing transatlantic trade and investment, ${ }^{46}$ it seems likely there would be considerable pressure on regulators to accept regulations from the other side, notably through mutual recognition even when there may be different levels of regulations. ${ }^{47}$ In addition, delays for new regulations appear inevitable as major additional steps and requirements will be necessary. These would appear to include formal consultation at an early stage with business; according to the Financial Times, '[t]he US is using transatlantic trade negotiations to push for a fundamental change in the way business regulations are drafted in the EU to allow business groups greater input earlier in the process', quoting from top US trade officials (Financial Times 2014). ${ }^{48}$ In the US, this approach has resulted in a number of major delays and blockages to new regulation; it is described as 'the delay game' by the National Resources Development Council in a report that examines this question (Sass and Rosenberg 2011).

This additional weight on regulators could have major consequences on regulations being undertaken in Europe. It could well lead to less regulations

44. HLWG (2013: 2); European Commission (2013b: 4).

45. 'While good regulatory practices appear also in other trade agreements, TTIP is set to become the first one that ensure their respect through an enforcement mechanism.'

46. European Commission (2013b: Section 3), 'Overall Objectives'. Also High Level Working Group Report ( HLWG 2013).

47. Bartl and Fahey state that 'vast scholarship' shows that officials in such situations, especially in an international trade context, give almost complete priority to trade, demoting other considerations to a secondary status. They give a number of references as examples (Bartl and Fahey 2014).

48. Exactly the same point is made in Shaffer in the context of earlier initiatives for transatlantic cooperation (2002: section IV). 
being undertaken, both because of increased stretching of limited resources, and to regulators becoming less likely to embark upon a potentially contentious path to a new regulation. ${ }^{49}$ From a trade perspective, where regulations are considered only or primarily as costs to companies, this makes perfect sense, but from a broader economic or other perspective, which includes the benefits of regulations also, the overall impact could be quite different.

However, democratic control over this process could in principle limit the extent to which regulations that are in reality at different levels across the Atlantic would be given mutual recognition, and an impact assessment of the TTIP needs to take the extent of such control into account. So far, from the publicly available material there appears to be little provision for such control in the envisaged agreement, including the wider debate that has often proved essential in the past for teasing out the implications of such regulatory decisions and exploration of options. The Commission's 'initial position paper' on 'Cross-cutting \& institutional provisions on regulatory issues' says that an essential component of the new framework would include '[a] streamlined procedure to amend the sectoral annexes of TTIP or to add new ones, through a simplified mechanism not entailing domestic ratification procedures' (European Commission 2013b: 5), which would seem to leave little scope for democratic control over the regulatory decisions involved. It is in these sectoral annexes that most regulatory changes will be made.

The role of 'stakeholders' has been emphasised strongly in the workings of the Regulatory Cooperation Council and, given the constraints and requirements, this appears to favour strongly certain stakeholders. First, 'joint proposals by US and EU stakeholders' are to be one of two sources of proposals for the RCC's work on regulations (the other is to be the 'parties' i.e. the US government or the EU as represented by the European Commission). As the sole formal objective of the RCC is to increase trade/investment, and with the economic gains so tiny, it would appear that just one stakeholder would have both the incentive and the means to participate successfully given what would be involved, i.e. business and in particular large business and its associations. The incentive would be to reduce the private cost of regulation to itself. Second, a 'multi-stakeholder advisory committee' is 'to regularly meet and work with ... the regulators in crafting regulatory measures or [in] taking decisions how to further compatibility of existing one[s] (e.g. through mutual reliance, [mutual] recognition etc.)' (European Commission 2013c, emphasis and square brackets added). Again, in this case, the work required for the stakeholders would be very great to achieve success.

The only communication with the public that is indicated for the RCC is that it would once a year 'release to the public' a programme 'outlining the planned

49. Parallel concerns have been expressed for example by the German small and medium business association BVMW, which issued a strong statement opposing the inclusion of investor-state dispute resolution in the TTIP, seeing it as a threat to public regulation and to state jurisdiction (BVMW 2014). 
and ongoing regulatory cooperation activities and objectives and reporting on the implementation of sectoral undertakings and other priority actions' (European Commission 2013c, emphasis added). This would appear to indicate that there is no intention to release its proceedings or detailed discussions on these issues. No mention is made of any public communication by the working groups themselves. Further, from the indications so far it appears that the European Parliament may well have little engagement in or oversight of the work of the Regulatory Cooperation Council and its working groups. ${ }^{50}$

Taking all these various indications together, it seems very likely that the benefits of regulations would be affected by the TTIP, and potentially to a considerable degree. To get a deeper appreciation of what might be at stake, we need to consider how such benefits might be assessed. We focus here on economic perspectives on the matter, especially for comparison with the economic impact studies, but fully recognise that this addresses just part of a more complete perspective needed for a full assessment which would cover social and environmental aspects more profoundly.

\subsection{Economic analyses of benefits and costs of regulations}

The main approach to regulation used in the economics of public policy in recent decades has emphasised the aim of 'internalising externalities'. This is included in the EU Treaty under Article 191(2) as 'the polluter should pay'. This means providing incentives to companies not to overproduce things that carry costs for others, so-called 'negative externalities'. Thus, for example, polluting activities are taxed so that companies have an incentive to reduce pollution and so the costs to others. However, removing such regulations would transfer costs (in the sense of the impact of pollution) back onto consumers, workers and the environment, and take away the incentive for companies to take account of the effects of such negative externalities, including for switching to substitute products or to cleaner production methods.

Regulations have increasingly been assessed using quantitative economic analysis before they are passed, both in the US and the EU. Cost-benefit analysis is the main method, especially in the US, where all "significant" regulations - meaning all with an impact on the economy greater than $\$ 100$ million in terms of either costs or benefits in at least one year - of the Executive Agencies (such as the Department of Health and Human Resources, of Transportation, the Environmental Protection Agency), have to undergo a costbenefit analysis. This is vetted by the Office of Information and Regulatory Affairs (OMB 2013: $11 \mathrm{ff}$ ). In the EU, measures with a significant impact have to undergo an assessment of costs and benefits (European Commission 2009). ${ }^{51}$

5o. To judge from Alemanno's report for the European Parliament (Alemanno 2014).

51. Cost-benefit analysis has increasingly been used in the EU, as well as cost-effectiveness analysis (where the objective of the measure is already fixed and only the costs are assessed) and multi-criteria analysis. Because of various issues in applying cost-benefit analysis, in many cases internationally partial assessments are made. 
However, while it has been easier to quantify the costs, especially the resources expended to implement the regulations, benefits can be more difficult to quantify, and various methods have been developed to estimate these, not without controversy. Arguably, as indicated in a number of critical studies of the use of cost-benefit analysis, the benefits are often underestimated (Ackerman and Heinzerling 2004; Ackerman 2008; Rose-Ackerman 2013). The point here is that a large body of work exists that estimates the benefits of regulations, and this is not taken into account by the analyses of the TTIP.

Overall estimates of the costs and benefits of regulations have been put together for the US by the Office of Information and Regulatory Affairs (OIRA), part of the bipartisan Office of Management and Budget (OMB). The results for all 'economically significant' US regulations reviewed by them over the period 2000-2012 for which data are available are shown in Figure 1 below. It can readily be seen that the benefits are estimated to outweigh the costs in every year, and do so by a factor of more than six on average over the whole period. ${ }^{52}$ The TTIP economic impact studies, however, focus exclusively upon the light-shaded bars in Fig. 1, or more correctly part of them, and ignore any effects on the benefits of regulations, the black bars in the figure.

Figure 1 The costs and the benefits of 'major' US regulations according to the US OIRA

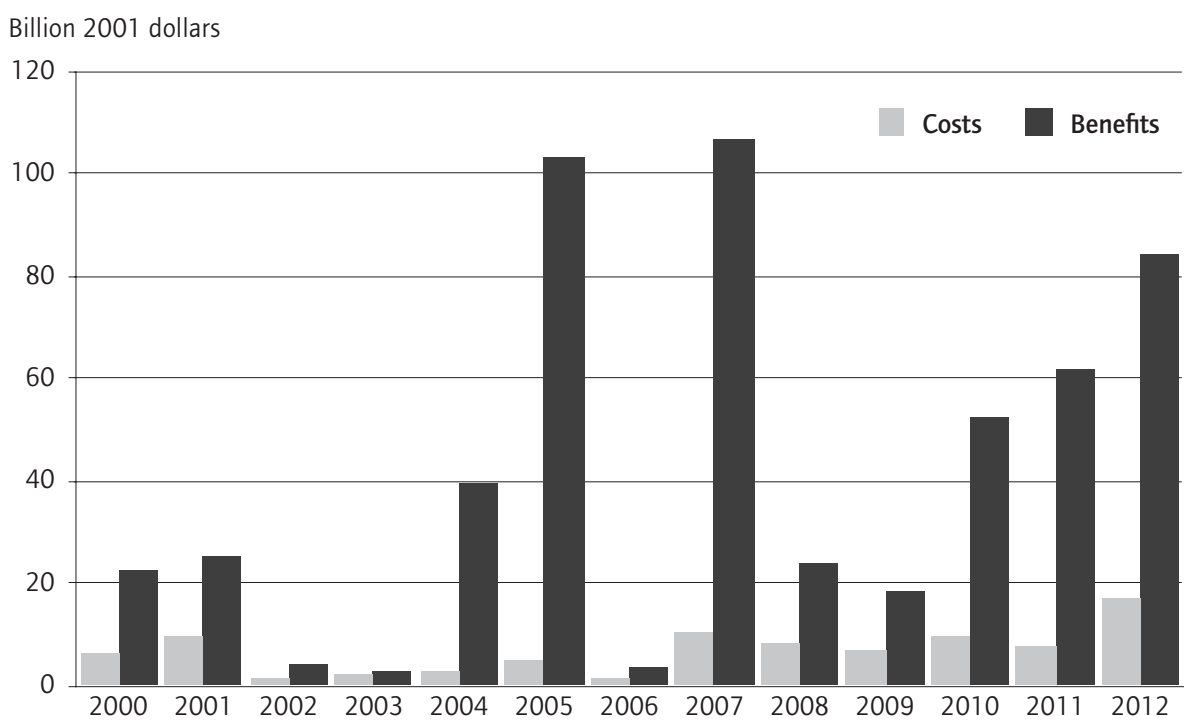

Source: OIRA Annual Report to Congress on the Benefits and Costs of Federal Regulations 2010, tables 1-3, B-1; draft 2013 report table 1-3

52. Cf Irons and Shapiro (2011). The figures only include the Executive Agencies and do not include Independent Agencies such as the Federal Reserve and the Securities Exchange Commission. 


\subsection{Five examples of regulation}

We now look briefly at five examples of areas where regulations can have a substantial impact, both as illustrations of regulatory benefits and in some cases of their relationship to the costs of regulation: climate change, toxic chemicals, carcinogens at work, the cost of "non-application" of the environmental acquis in the EU, and financial regulation. All are relevant areas for the TTIP. ${ }^{53}$

The most widely accepted assessment of climate change costs has been the Stern Review (Stern 2007) in which it was estimated that, without a major and early change in direction from the existing "business as usual" path, the costs to the world due to climate change would be an average of 5\%-20\% of GDP each year between 2001 and 2200, while the costs of action to reduce the worst effects of climate change can be limited to around 1\% per year (Stern 2007: vi, 143-144). There has been considerable debate over these findings and there appears to have been an underestimation of the likelihood of catastrophic outcomes which would further increase the costs of climate change (Ackerman 2009; Baer and Spash 2008). More recently, Stern has said that due to lack of action in the meantime, a much worse outcome was now considerably more likely (Stern 2013a and b). The size of the benefits (i.e. avoiding the costs that result from not acting) is large indeed, and clearly far larger than the costs of regulation.

However, climate change related NTBs in both the EU and US mentioned in the Annex are considered by companies as priorities apparently for diminishing or bypassing in the TTIP. The change in regulatory regime under the TTIP as described in the previous section would make addressing climate change more difficult in future, as any significant regulation on either side may well be considered a barrier to trade, not to mention the likely fate of the sort of measures that would be needed to address adequately the challenge.

Toxic chemicals can have very large costs. An example is the case of PCBs (polychlorinated biphenyls), a group of chemicals persistent in the environment and found to cause reproductive problems in animals and nervous disorders in humans. The costs of cleaning them up for the EU as a whole - for removal, transport, decontamination, permanent storage and various administrative costs - have been estimated to be at least $€ 15 \mathrm{bn}$, from 1971 to 2018. However, this does not include the costs from human health effects, or damage to biodiversity or ecosystems. This may be one of the more costly cases estimated in Europe to date, but it does indicate the economic importance of regulation in avoiding such costs. ${ }^{54}$

53. We do not include food safety among the examples in the text, but losses from foodborne diseases for the US have been estimated at several tens of billions of dollars per year, with one in six people getting ill per year. The benefits from regulations that would successfully reduce this would be very large (Centers for Disease Control 2014; Scharff 2012; Hoffmann et al. 2013).

54. A wider discussion of the issues and of the above study can be found in Ackerman (2008). 
Many examples in the Annex relate to the regulation of toxic chemicals. Especially important in this and related areas, the EU has enshrined the precautionary principle in the Treaty for environmental policy (article 174.2), and implemented it after an extensive and lengthy debate in the REACH chemicals directive in 2006, for example. The European courts have given it a broader application and its use has been extended to other areas such as food safety, trade and research. ${ }^{55} \mathrm{REACH}$ also appears strongly in the Annex to this paper among the priority regulations that according to business viewpoint should be addressed in the TTIP.

Each year in Europe approximately 65,000 people die from the effects of carcinogens at work (Cherrie et al. 2011: 8), over twice the number who die from car accidents. The estimate is based inter alia on a highly detailed UK study (Rushton et al. 2012) involving a number of the same authors (Rushton et al, 2012) which found that $5.3 \%$ of cancer deaths in the UK were due to cancer at work. Cherrie et al. (2011) postulate a likely similar burden in many European Member States although the exact magnitude may vary between countries. For Finland, which has a very detailed system for studying cancer at work, the estimate was $8 \%$ of all cancer deaths.

A UK study found that $85 \%$ of such deaths came from 10 chemical agents and it appears that a small number are also responsible elsewhere in Europe. The lead author of a study for the EU on the subject foresaw the possibility of 'eliminating occupational cancer as a public health issue' (Cherrie et al. 2011: 8) by tightly controlling exposure to a relatively small number of chemical carcinogens, and that by doing so it could be possible to reduce the proportion of occupational cancer deaths to less than $1 \%$ of all cancer deaths, compared to $5 \%$ today. Thus regulation to prevent or limit exposure to such substances at work can have very large benefits (see also Mengeot et al. 2007).

A study in 2011 for the European Commission on the costs of the nonapplication of the environmental acquis - i.e. costs incurred due to the incomplete implementation of the environmental regulations that had been agreed at EU level - found these costs to be approximately $€_{50}$ billion per year in relation to the minimum targets, i.e. those currently legally binding (COWI et al. 2011). Including the agreed future legally binding targets, to be implemented by 2020, increases the costs to $€ 200-300$ billion per year, albeit with a substantial margin of error, but covering only the environmental damage costs. These costs are related to problems in, for example, the waste sector, local air quality, biodiversity/nature, and water including the cost of flooding.

Low levels of financial regulation are widely accepted to have been a major contributory factor to the financial crisis that began in 2007. Crises such as this cause permanent losses of output, which means the loss recurs every year.

55. A recent and well-informed discussion of the precautionary principle and its use can be found in von Schomberg (2012); on legal and other aspects see Rose-Ackerman (2013). The evidence in a variety of areas is reviewed in two major reports with multiple contributors published by the European Environment Agency (EEA 2002 and 2013). 
The cost of the financial crisis has been estimated at between $\$ 60$ trillion and $\$ 200$ trillion for the world economy over time in terms of lost world output (Haldane 2010). Even if some assumptions made could be questioned, the numbers would still remain very large indeed and are very much related to poor and low levels of regulation. The respected NGO Finance Watch has stated to a European Parliamentary hearing their concerns that the TTIP would result in a 'regulatory chill' in finance and would undermine the multilateral regulation needed for the sector which is very much international in its activities (Philipponnat 2014).

To conclude on regulation, adding in the benefits of regulations in the context of TTIP could fundamentally change the outcome of the assessment if these benefits are negatively affected to even a small degree, given that they are so large. The TTIP is not presented as an agenda for deregulation, but the emphasis on seeing regulations as costs and the regulatory institutions and processes to be set up makes a levelling down much more likely than a levelling up. Removal of even a small proportion of the benefits of regulations could still dwarf the very small economic gains that the studies estimate would take place. 


\section{Conclusion}

The TTIP negotiations have been under way since July 2013, with claims that it will bring substantial economic benefits. However, the benefits estimated by the key impact study for the European Commission are very small indeed: onetwentieth of one per cent increase in growth rate in the most optimistic scenario, for a period of 10 years. There would be an increase in disposable income of $€ 2.60$ per week per person in the EU in the most optimistic scenario, or $€ 1.50$ in a more realistic one, after 10 years. Essentially, on these estimates the TTIP would have no impact in getting us out of the crisis.

In terms of employment, the impact study for the European Commission assumes full employment, and so the gains take place in wages rather than employment. The Ifo studies find a small employment increase in their main study for the Ministry, but the highly profiled Bertelsmann/Ifo study finds a multiple of that, at over two million jobs across the Atlantic. However, this does not include many losses in jobs; the lower figure does.

The results of the studies have frequently been presented in a way that is not confirmed when examined more closely. Some forms of presentation are particularly problematic: first, a one-sided presentation whereby only export increases are presented but not the simultaneous and sometimes higher increase in imports, or job increases without the parallel job losses. Second, results from the most optimistic assumptions or scenario are presented, without sufficiently indicating the basic assumptions behind them, and which on closer look often turn out to be quite implausible. Also, in some cases, where different studies are done by the same group which reach often widely differing findings, only the most optimistic findings are presented, without reference to the others.

The scenarios underlying some of the most widely quoted results including those above assume unlikely developments. In the case of the CEPR study, the assumption is that the US would be half-way to becoming a fully embedded member of the EU after 10 years. Because of the entrenched differences in ways of regulating across a wide range of areas, or in technical standards (used by regulations) in many areas, this seems highly unlikely. Using more realistic assumptions would give even lower results than those identified above.

Because of the approach used by all the impact studies, both at EU and national levels, the estimates are entirely one-sided concerning the core issue for the TTIP, regulations. All consider only the costs of regulations, and not the benefits. The benefits of regulations are several times greater than their costs 
on average, and the official US overall estimate for economically significant regulations examined over 2000-2012 is that the benefits would be six times larger than the costs. The benefits from regulations in various areas such as climate change, other environmental aspects, health and safety at work, hazardous chemicals, food safety and financial regulation are very large indeed.

If through mutual recognition of different levels of regulation, they are put in competition with each other across the Atlantic, and if the differences are associated with lower costs, the result is likely to be a race to the bottom in regulation. There seems to be very little likelihood in the foreseeable future of a common agenda that implies support for higher standards of regulation, such as US adoption of the European REACH system. Also, if the regulatory cooperation processes proposed lead to a loss of democratic control over the ability to regulate and relatedly to a diminution in regulation, it could have major effects. If the TTIP goes ahead as planned according to the official information publicly available so far, both published and leaked, including the key role anticipated for business in proposing regulatory change, this seems very possible and perhaps likely. Because the benefits of regulations are so large, even a small decrease would swamp the tiny economic gains foreseen for the TTIP.

We have not discussed in this paper the issue of the EU-US using the TTIP to set a trade agenda that others would have to follow if they were to get access to these large markets. This is a key part of the rationale for TTIP (HLWG 2013). However, with a likely lowering rather than raising of regulatory standards at the EU level, the notion that it would set a 'gold standard' for the rest of the world does not seem correct. The agenda explicitly targets usual development policies for building local resources through for example public purchasing or subsidy at a local level, typically to overcome market failures and often vital to local development. The foundational document for the TTIP, the HLWG report targets 'localization barriers to trade: measures designed to protect, favour, or stimulate [sic] domestic industries, services providers, or intellectual property at the expense of imported goods, services, or foreign-owned or foreigndeveloped intellectual property.' There are no doubt many terms that could be used to describe this, but a gold standard for development would not appear to be among them. In such an environment one could also expect that important issues such as labour standards would be ignored.

We have examined the economic impact studies, considered their results on their most optimistic findings, identified a very large gap in those studies and looked at what difference it might make if that gap was taken into account. At the end of the day, the potential loss of democratic control over regulations and the consequences this might have for the benefits from regulations needs to be weighed up against the economic gains from the TTIP, which can be summed up as the equivalent of the cup of coffee per week for each person on both sides of the Atlantic. 


\section{Annex: Priority NTMs for a transatlantic agreement in Ecorys study (2009)}

The following are selected from the list of the priority Non-Tariff Measures given in the Ecorys study (Berden et al. 2009: Annex IX). They are organised by sector as in the original and are in rank order of importance as identified by the Ecorys study. The selection here is based on items that may differ significantly in level of regulation across the Atlantic, or are otherwise of interest for the discussion here. 'EU to US' means that they are of concern to suppliers from the EU when exporting to the US, and vice versa for 'US to EU'.

\section{Automotives}

\section{EU to US}

Taxation of cars with high fuel consumption (CAFE = Corporate Average Fuel Economy)

Gas Guzzler Tax

Requirements to Reduce Idling Emissions from New and In-Use Trucks, Beginning in 2008

\section{US to EU}

REACH regulation

Safety and health measures

WEEE Directive (2002/96/EC) [Waste Electrical and Electronic Directive]

\section{Chemicals}

\section{EU to US}

Classification and labelling requirements for chemical products

Restrictions on use of specific chemicals

Imported pesticides/biocides must be notified to the EPA [Environmental Protection Agency]

\section{US to EU}

Divergence in risk assessment requirements between REACH and TSCA

RoHS and restrictions on hazardous substances [RoHS: 'Restriction of the use of certain hazardous substances in electrical and electronic equipment']

Product Labelling requirements (including eco-labelling)

Testing requirements / Risk assessment for plant protection and biocidal products

Restrictions on use of dangerous substances in consumer products (Dangerous Substances Directive, 76/769/EEC)

Registration requirements for biocidal products that contain active substances

EU Intellectual property rights which are less broad than the US ones

Testing requirements / Risk assessment for pesticides / biocidal products and pesticides

$\mathrm{REACH}$ risk assessment requirements which differ from those applied in US

Candidate list of substances of very high concern in REACH 


\section{Food \& beverages}

\section{EU to US}

Certification of agricultural products as organic

High and different level of SPS measures [SPS: Sanitary and Phytosanitary Standards]

\section{US to EU}

EU product standards (SPS) which differ (are more strict) from international standards

EU labeling requirement laws

Traceability and labeling of biotechnology foods

Maximum limits on mycotoxins for a variety of foodstuffs (including cereals, fruit and nuts)

Requirements on US products to classify them as "organic"

Protection of geographical indicators (Gls) of wine and spirits

REACH regulations

High and different level of SPS measures

\section{Pharmaceuticals}

\section{EU to US}

Restrictions or bans on use of specific chemicals

Prior authorization for sensitive product categories

\section{US to EU}

International reference pricing

Therapeutic reference pricing

\section{Insurance services}

\section{EU to US}

Collateral requirements (or especially US reinsurance services)

Federal excise tax for insurers (cascading tax)

US to EU

Regulatory capital requirements in reinsurance

The proposed EC legislation known as Solvency II

\section{Transportation services}

\section{EU to US}

Environmental regulations e.g. Clean Air Act

Restrictions on the use of foreign temporary workers

\section{US to EU}

Restrictions on the use of foreign temporary workers 


\section{References}

Ackerman F. (2008) Poisoned for pennies: the economics of toxics and precaution, Washington DC, Island Press.

Ackerman F. (2009) Much less wrong: the Stern Review versus its critics, in Ackerman F. (2009) Can we afford the future? The economics of a warming world, London, Zed Books.

Ackerman F. and Gallagher K. (2008) The shrinking gains from global trade liberalization in computable general equilibrium models: a critical assessment, International Journal of Political Economy, 37 (1), 50-77.

Ackerman F. and Heinzerling L. (2004) Priceless: on knowing the price of everything and the value of nothing, New York, New Press.

Alemanno A. (2014) The Transatlantic Trade and Investment Partnership and the parliamentary regulatory cooperation, Report to European Parliament. http://www.europarl.europa.eu/committees/en/studies.html

Arkolakis C., Costinot A. and Rodriguez-Clare A. (2012) New trade models, same old gains, American Economic Review, 102 (1), 94-130.

Baer P. and Spash C. (2008) Cost-benefit analysis of climate change: Stern revisited, CSIRO Working Paper 2008-07, Canberra, Commonwealth Scientific and Industrial Research Organisation.

Bartl M. and Fahey E. (2014) A postnational marketplace: negotiating the Transatlantic Trade and Investment Partnership (TTIP), in Fahey E. and Curtin D. (eds.) A transatlantic community of law: legal perspectives on the relationship between the EU and US legal orders, Cambridge, Cambridge University Press.

Berden K.G., Francois J., Thelle M., Wymenga P. and Tamminen S. (2009) Non-tariff measures in EU-US trade and investment: an economic analysis, Rotterdam, ECORYS Nederland BV.

Bureau J.-C et al. (2014) Risks and opportunities for the EU agri-food sector in a possible EU-US Trade Agreement, Study for European Parliament. http://www.europarl. europa.eu/RegData/etudes/STUD/2014/514007/AGRI_IPOL_STU(2014)514007 EN.pdf

BVMW (2014) Stellungnahme im Rahmen des Konsultationsverfahrens der EUKommission zum Investitionsschutz im geplanten Transatlantischen Freihandelsabkommen TTIP, Positionspapier, Berlin, Bundesverband mittelständische Wirtschaft e.V.

Centers for Disease Control (2014) Estimating foodborne illness: an overview. http://www.cdc.gov/foodborneburden/estimates-overview.html

CEN/CENELEC (2013) Position paper on EU-US Transatlantic Trade and Investment Partnership (TTIP) - Technical Barriers to Trade - Initial EU Position Paper, September 2013. http://www.cencenelec.eu/news/policy_opinions/PolicyOpinions/ PositionPaperTTIP.pdf

Cherrie J. et al. (2011) Health, socio-economic and environmental aspects of possible amendments to the EU Directive on the protection of workers from the risks related to exposure to carcinogens and mutagens at work: summary report, Report to European Commission. http://ec.europa.eu/social/BlobServlet?docld=10149\& langld=en

COWI, ECORYS and Cambridge Econometrics (2011) The cost of not implementing the environmental acquis. http://www.ec.europa.eu/environment/enveco/economics_ policy/pdf/report_sept2011.pdf 
Derbel H., Dammak N. and Chkir A. (2013) Intra-industry trade and labour market adjustment in France, Global Journal of Human Social Science Research: Economics, $13(4), E$

Egger P., Larch M., Staub K., and Winkelmann R. (2011) The trade effects of endogenous preferential trade agreements, American Economic Journal: Economic Policy, 3 (3), 111-143.

European Commission (2009) Impact assessment guidelines, SEC(2009) 92.

European Commission (2013a) Impact assessment report on the future of EU-US trade relations, Commission Staff Working Document, SWD(2013) 69 final, 12 March 2013.

European Commission (2013b) EU-US Transatlantic Trade and Investment Partnership: trade cross-cutting \& institutional provisions, Initial EU position paper, July 2013.

European Commission (2013c) TTIP: cross-cutting disciplines and institutional provisions. Position paper - Chapter on Regulatory Coherence. http://corporateeurope.org/ sites/default/files/ttip-regulatory-coherence-2-12-2013.pdf

European Commission (2013d) EU-US Transatlantic Trade and Investment Partnership: technical barriers to trade, Initial EU position paper, June 2013.

European Commission (2013e) Communication from the Commission to the European Parliament, the Council, the European Economic and Social Committee and the Committee of the Regions - Regulatory Fitness and Performance (REFIT): results and next steps, COM(2013) 685 final, 2 October 2013.

European Commission (2013f) Transatlantic Trade and Investment Partnership: the economic analysis explained. http://trade.ec.europa.eu/doclib/docs/2013/ september/tradoc_151787.pdf

EEA (2002) Late lessons from early warnings: the precautionary principle 1896-2000, Copenhagen, European Environmental Agency.

EEA (2013) Late lessons from early warnings: science, precaution, innovation, Copenhagen, European Environmental Agency.

Felbermayr G., Heid B. and Lehwald S. (2013) Transatlantic Trade and Investment Partnership (TTIP): who benefits from a free trade deal? Part 1: macroeconomic effects, Gütersloh, Bertelsmann Stiftung.

Felbermayr G., Heid B., Larch M. and Yalcin E. (2014) Macroeconomic potentials of Transatlantic Free Trade: a high resolution perspective for Europe and the world, CESifo Working Paper 5019, Munich, Ifo Institute - Center for Economic Studies.

Felbermayr G. and Larch M. (2013) The Transatlantic Trade and Investment Partnership (TTIP): potential, problems and perspectives, CESIfo Forum 2/2013, 49-60.

Felbermayr G., Larch M., Flach L., Yalcin E. and Benz S. (2013) Dimensionen und Auswirkungen eines Freihandelsabkommens zwischen der EU und den USA, München, IFO Institut.

Felbermayr G., Lehwald S., Schoof U. and Ronge M. (2013) States, branches of industry, and education levels: who will benefit in Germany from a Transatlantic Trade and Investment Partnership (TTIP)? Part 2: microeconomic effects in Germany, Gütersloh, Bertelsmann Stiftung.

Felbermayr G., Jung B. and Larch M. (2013) Icebergs versus tariffs: a quantitative perspective on the gains from trade, CESIfo Working Paper 4175, Munich, Ifo Institute - Center for Economic Studies.

Financial Times (2014) US pushes for greater transparency in EU business regulation, 23 February 2014. 
Fontagné L., Gourdon J. and Jean S. (2013) Transatlantic trade: whither partnership, which economic consequences?, CEPII Policy Brief 1, Paris, Centre d'études prospectives et d'informations internationales.

Francois J. Manchin M., Norberg H., Pindyuk O. and Tomberger P. (2013) Reducing Transatlantic barriers to trade and investment: an economic assessment, London, Centre for Economic Policy Research.

Francois J. and Manchin M. (2014) Quantifying the impact of a Transatlantic Trade and Investment Partnership (T-TIP) Agreement on Portugal, London, Centre for Economic Policy Research.

Freytag A., Draper P. and Fricke S. (2014) The impact of TTIP. Volume 1: economic effects on the transatlantic partners, third countries and the global trade order, Berlin, Konrad Adenauer Stiftung.

GAO (2007) Comparison of U.S. and recently enacted European Union approaches to protect against the risks of toxic chemicals, Washington DC, United States Government Accountability Office.

GAO (2013) EPA has increased efforts to assess and control chemicals but could strengthen its approach, Washington DC, United States Government Accountability Office.

Gomez A. (2013) Chemical Regulation: observations on the Toxic Substances Control Act and EPA implementation, Washington DC, United States Government Accountability Office.

Haldane A. (2010) The $\$ 100$ billion question. http://www.bis.org/review/r100406d.pdf Heid B. and Larch M. (2013) International trade and unemployment: a quantitative framework, CESifo Working Paper 4013, Munich, Ifo Institute - Center for Economic Studies.

HLWG (2013) Final Report - High Level Working Group on Jobs and Growth, 11 February 2013. http://trade.ec.europa.eu/doclib/docs/2013/february/tradoc_ 150519.pdf

Hoffmann S. and Anekwe T. (2013) Making sense of recent cost-of-foodborne-illness estimates, Economic Information Bulletin 118, Washington DC, United States Department of Agriculture.

Irons J. and Shapiro I. (2011) Regulation, employment, and the economy: fears of job loss are overblown, EPI Briefing Paper 305, Washington DC, Economic Policy Institute.

Leromain E. (2013) Measuring the welfare gains from trade: the case of China's entry into the WTO, HAL Economics and finances. http://dumas.ccsd.cnrs.fr/dumas-00905755

Mengeot M., Musu T. and Vogel L. (2007) Occupational cancer: the Cinderella disease, Brussels, ETUI.

OMB (2013) 2012 Report to Congress on the benefits and costs of Federal Regulations and unfunded mandates on State, Local, and Tribal Entities, Washington DC, Office of Management and Budget.

Pelkmans J. (2012) Mutual recognition: economic and regulatory logic in goods and services, Bruges, College of Europe.

Philipponnat T. (2014) Speech at European Parliament's ECON Committee public hearing on 'The Transatlantic Trade and Investment Partnership (TTIP) and Financial Services Regulation', 18 March 2014. http://www.europarl.europa.eu/document/ activities/cont/201403/20140320ATT81368/20140320ATT81368EN.pdf 
Raza W., Grumiller J., Taylor L., Tröster B. and von Arnim R. (2014) ASSESS_TTIP: assessing the claimed benefits of the Transatlantic Trade and Investment Partnership (TTIP), Vienna, Austrian Foundation for Development Research.

Rose-Ackerman S. (2013) Precaution, proportionality, and cost/benefit analysis: false analogies, European Journal of Risk Regulation, 4 (2), 281-286.

Roubini, N. and S. Mihm (2011) Crisis Economics, London, Penguin Books.

Rushton L. et al. (2012) The burden of occupational cancer in Great Britain: overview report, London, Health and Safety Executive.

Santiago E. (2014) Challenges \& benefits of regulatory cooperation for the EU \& US industry and consumers: TTIP \& standardization matters, Presentation to European Parliament hearing on 'The Impact of the TTIP on the Internal Market', 17 March 2014.

Sass J. and Rosenberg D. (2011) The delay game: how the chemical industry ducks regulation of the most toxic substances, New York, National Resources Development Council.

Scharff R. (2012) Economic burden from health losses due to foodborne illness in the United States, Journal of Food Protection, 75 (1), 123-131.

Shaffer G. (2002) Reconciling trade and regulatory goals: the prospects and limits of New Approaches to Transatlantic Governance through Mutual Recognition and Safe Harbor Agreements, Columbia Journal of European Law, Fall 2002, 29-77.

Stephan S. (2014) Comments on the claimed benefits of the TTIP, Slides presented at TTIP Debat, Copenhagen, 26 september 2014. http://www.boeckler.de/pdf/imk vortrag_stephan_2014_09_26.pdf

Stern N. (2007) The economics of climate change: the Stern review, Cambridge, Cambridge University Press.

Stern N. (2013a) 'I got it wrong on climate change - it's far, far worse', The Observer, 26 January 2013. http://www.theguardian.com/environment/2013/jan/27/nicholasstern-climate-change-davos? INTCMP $=\mathrm{SRCH}$

Stern N. (2013b) Climate change worse than expected, argues Lord Stern, Scientific American, 3 April 2013. http://www.scientificamerican.com/article/climate-changeworse-than-expected-argues-lord-stern/

Taylor L. and von Arnim R. (2006) Modelling the impact of trade liberalisation: a critique of computable general equilibrium models, Oxfam Research Report, New York, New School for Social Research.

Vandenbussche H., Wooton I. and Venables A. (2002) Enhancing economic cooperation between the EU and the Americas: an economic assessment, London, Centre for Economic Policy Research.

von Bahr J. and Jansen J. (2004) Cost of late action - the case of PCB, Copenhagen, Nordic Council of Ministers.

von Schomberg R. (2012) The precautionary principle: its use within hard and soft law, European Journal of Risk Regulation, 3 (2), 147-156.

WTO (2011) World Trade Report 2011.The WTO and preferential trade agreements: from coexistence to coherence, Geneva, World Trade Organization.

All links were checked on 7 January 2015 